\title{
In memory of Cliff Malcolm
}

\author{
Glen S. Aikenhead
}

Received: 17 April 2008/Accepted: 17 April 2008/Published online: 5 July 2008

(C) Springer Science+Business Media B.V. 2008

Cliff passed away on March 24, 2008, at the age of 64, in Melbourne, Australia, with family around him. He had been fighting cancer for 2 years.

Cliff was born and raised in Australia where he became fascinated with physics. At the University of Melbourne, he completed an Honors Physics degree and a Diploma in Education, whereupon he became a Lecturer in Physics at what is now the Melbourne State College (formerly the Secondary Teachers College). Typical of his courage and innovative thinking, Cliff decided to pursue a $\mathrm{PhD}$ in nuclear physics, which he completed in 1972 at the University of Saskatchewan, Canada. He returned to Melbourne State College as a lecturer in both Primary Science Education and Physics Education. From the mid 1980s he led major science curriculum and policy projects for the Victorian Ministry of Education, resulting in Curriculum Frameworks (P-10) and study designs in the sciences for the Victorian Certificate of Education (11-12). In the early 1990s he became Coordinator of the National Science Curriculum and Teaching Program and lead author of the influential Australian Science Profile.

Cliff moved to South Africa, first as a visiting professor at the University of the Witwatersrand in Johannesburg (1997-2000), then as professor of science education and Director of the Centre for Education Research, Evaluation, and Policy, at the University of Durban Westville (2000-2006), now the University of KwaZulu Natal. He also took on the editorship of the African Journal of Research in Mathematics, Science and Technology Education. His main research interests continued to be learner-centred education, equity, and social justice; with much of his South African work conducted in rural areas and townships. Cliff was active in science education policy development in South Africa, taking a leading role in framing the Nelson Mandela Foundation study of rural education.

Cliff returned to Australia in 2006 to be close to his family and to take up a position at Deakin University. He participated in a major collaborative research project related to rural school/community professional development in the state of Victoria, thereby enhancing his commitment to rural science education. He was diagnosed and treated for cancer later in

G. S. Aikenhead $(\bowtie)$

Department of Curriculum Studies, College of Education, University of Saskatchewan,

28 Campus Drive, Saskatoon, SK, Canada S7N 0X1

e-mail: glen.aikenhead@usask.ca 
2006. Having experienced a complete remission of his cancer in early 2007, Cliff reimmersed himself in the Deakin project and contributed rich data and analyses for his team.

He also agreed to participate in this forum for Moyra Keane's article. Tragically, the cancer relocated aggressively in his spine a few months later. Yet Cliff insisted on fulfilling his commitment to the forum. During rare moments of energy and clarity, he eagerly communicated with the other forum contributors from September to November. This activity turned out to be his last professional project.

Cliff was an academic warrior for equity and social justice. Throughout his career, he knew what various students needed from school science, and he never compromised on this knowledge when he prepared lessons, developed programs, produced materials, and engaged in the politics of science education. His supervision of graduate students and his dedication to science teachers were legendary. He is admired by the science education community worldwide.

Cliff was predeceased by his wife, Marie, in 1992. He is survived by his children Steve, Marina, and Wes. Cliff was special for many reasons, but mostly for being a great Dad and Grand-dad. 